Berenika Janusz

(Uniwersytet Jagielloński)

\title{
Potencjał demograficzny Chin w XXI w. w kontekście migracji wewnętrznych i polaryzacji społeczeństwa
}

Jednym z czynników, które w XXI w. stanowić będą o mocarstwowym potencjale Azji, jest jej potężna siła demograficzna. W przypadku Chin, najludniejszego kraju świata, siła ta urasta wręcz do rangi symbolu. Jednakże to, co w teorii świadczyć powinno o mocarstwowej pozycji Państwa Środka, w praktyce może stać się źródłem zjawisk prowadzących do konfliktów i zaburzeń społecznych. Wydaje się, że odpowiedź na pytanie, czy potencjał demograficzny to dla Chin jedynie źródło siły, czy być może wyzwanie nie jest prosta i jednoznaczna.

\section{Zarys pozycji demograficznej Chin w XXI w. Stan obecny, prognozy}

Populacja Chińskiej Republiki Ludowej liczyła w 1949 r. ok. $541 \mathrm{mln}$ mieszkańców ${ }^{1}$. Wbrew zawirowaniom historii, największy, dwustumilionowy wzrost liczby ludności ChRL odnotowano w dekadzie rewolucji kulturalnej. W 2005 r. Chiny miały już 1316 mln mieszkańców. Prognozy przewidują, co prawda, że ok. roku 2030 to Indie staną się najludniejszym krajem świata, jednak liczba ludności w Chinach utrzymywać się będzie na wysokim poziomie. Według uśrednionych prognoz Organizacji Narodów Zjednoczonych, liczba ludności Chin nieznacznie wzrośnie do 2050 r. (do ok. 1392 mln osób). Należy jednak zwrócić uwagę na to, iż scenariusze zakładające maksymalny wzrost liczby ludności mówią o ok. 1647 mln osób w 2050 r., natomiast te zakładające wzrost minimalny przewidują spadek tej liczby do ok. $1171 \mathrm{mln}$. Tak więc rozbieżności pomiędzy prognozami maksymalnymi i minimalnymi ONZ na rok 2050 wynoszą ponad $470 \mathrm{mln}$ osób (por. rys. 1 i 2).

${ }^{1} 541,60 \mathrm{mln}$; China Population Information and Research Center, http://www.cpirc.org. cn/en/totpope.htm ( $\operatorname{stan}$ z 20.10.2006). 


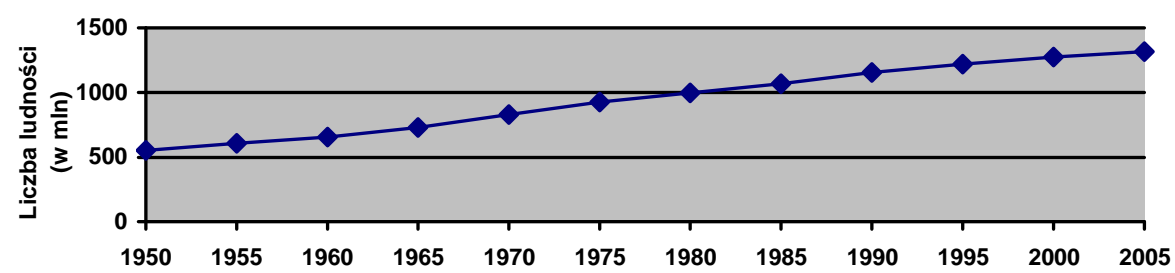

Rys. 1. Liczba ludności ChRL w latach 1950-2005

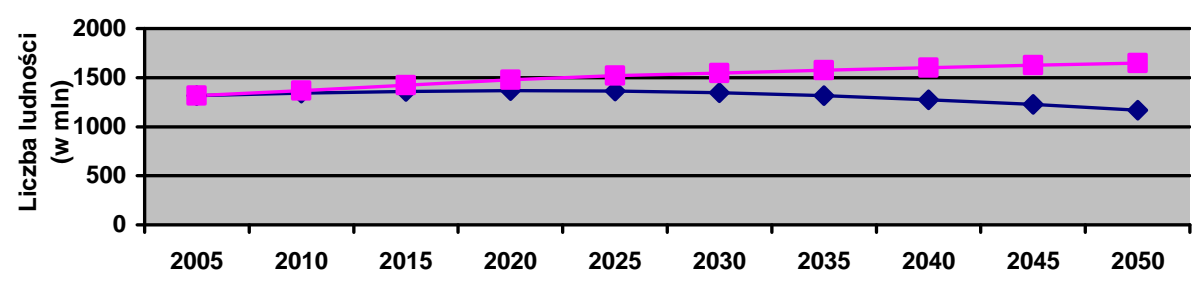

Rys. 2. Prognozy ONZ dotyczące liczby ludności Chin w latach 2005-2050 (scenariusz maksymalny i minimalny)

Ź ródło: opracowanie własne na podstawie World Population Prospects. The 2004 Revision and World Urbanization Prospects: The 2003 Revision, Population Division of the Department of Economic and Social Affairs of the United Nations Secretariat, Organizacja Narodów Zjednoczonych, http://esa.un.org/unpp (stan z 10.10.2006).

Według średnich prognoz ONZ, w 2050 r. przewaga Indii nad Chinami pod względem liczby ludności będzie przekraczać $200 \mathrm{mln}$ osób $^{2}$. Pod tym względem Chiny i Indie długo jeszcze będą dystansować wobec siebie resztę świata.

\section{Wewnętrzna struktura społeczeństwa chińskiego}

W 1950 r. ludność miejska stanowiła 13\% populacji Chińskiej Republiki Ludowej. W ciagu kolejnych 30 lat, przed rozpoczęciem reform gospodarczych, struktura społeczna zmieniła się nieznacznie na korzyść ludności miejskiej (zaledwie $20 \%$ w 1980 r.). W 2005 r. liczba mieszkańców wsi wynosiła, według statystyk ONZ, ok. 783 mln osób, natomiast liczba mieszkańców miast $533 \mathrm{mln}^{3}$. Biorąc jednak pod uwagę fakt, że liczbę pracowników migracyjnych

${ }^{2}$ World Population Prospects. The 2004 Revision and World Urbanization Prospects: The 2003 Revision, Population Division of the Department of Economic and Social Affairs of the United Nations Secretariat, Organizacja Narodów Zjednoczonych, http://esa.un.org/unpp (stan z 10.10.2006).

${ }^{3}$ Ibidem. 
(przenoszących się z wiosek do miast w poszukiwaniu pracy) niektóre źródła oceniają obecnie nawet na $150 \mathrm{mln}$, należy stwierdzić, iż rzeczywista liczba mieszkańców wsi i miast powoli się wyrównuje. Szacuje się, że do roku 2030 udział mieszkańców wsi w ogólnej liczbie ludności spadnie do ok. $40 \%{ }^{4}$. Jak widać więc, do największych zmian w strukturze społecznej Chin doszło w wyniku reform gospodarczych oraz ich bezpośrednich konsekwencji. Częściowa liberalizacja systemu rejestracji obywateli, tzw. hukou, zniesienie systemu racjonowania żywności ${ }^{5}$, a także ukryte bezrobocie na wsi oraz ogromne dysproporcje w standardzie życia mieszkańców wsi i miast doprowadziły do wielkich ruchów migracyjnych, a tym samym utrudniły prowadzenie rzetelnych statystyk. Proces intensywnej migracji na linii wieś - miasto jest typowy dla krajów rozwijających się. W Chinach zjawisko to nasila się, gdyż przez całe dekady migracja ludności wiejskiej do miast była sztucznie hamowana przez władze komunistyczne. Na migrację ze wsi do miast nakłada się w Chinach dodatkowo migracja $\mathrm{z}$ małych miast do dużych ośrodków miejskich (zwłaszcza tych będących stolicami prowincji), a także ruchy ludności na linii wieś - wieś. Grupy Chińczyków, których migracje wyznacza ten ostatni kierunek, stanowią najniższą pod względem hierarchii grupę migrantów i zaliczają się tym samym do jednej z najniższych warstw społecznych.

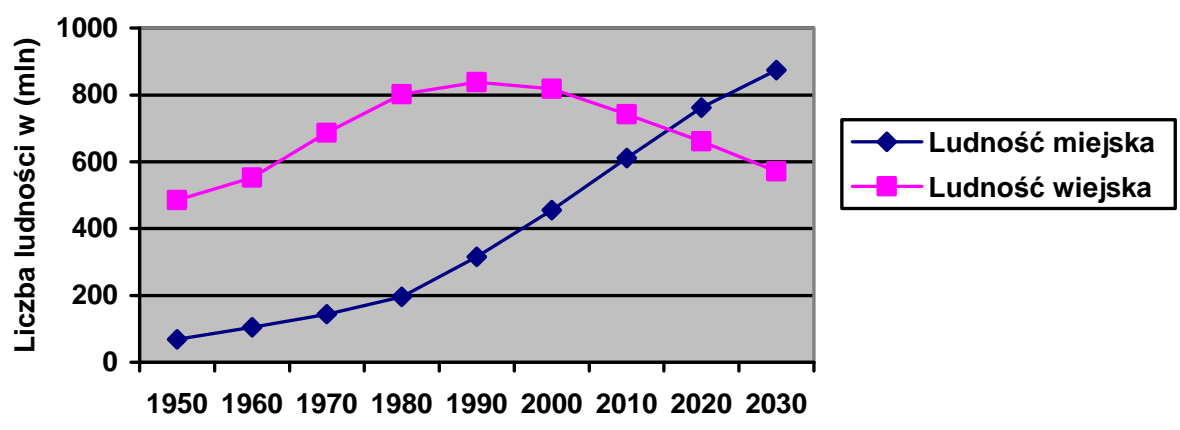

Rys. 3. Struktura społeczeństwa chińskiego ze względu na miejsce zamieszkania (1950-2030)

Ź ró dło: opracowanie własne na podstawie World Population Prospects. The 2004 Revision and World Urbanization Prospects: The 2003 Revision, Population Division of the Department of Economic and Social Affairs of the United Nations Secretariat, Organizacja Narodów Zjednoczonych, http://esa.un.org/unpp (stan z 10.10.2006).

\section{${ }^{4}$ Ibidem.}

${ }^{5}$ Pośrednio również wprowadzenie dowodów osobistych w latach osiemdziesiątych XX w. Por.: P. H u a n g, F. N. P i e k e, China migration country study, paper for Regional Conference on Migration, Development and Pro-Poor Policy Choices in Asia, Dhaka, czerwiec 2003, s. 13. 
Ludność miejska Chin jest silnie skoncentrowana wokół kilkudziesięciu największych ośrodków miejskich. W zaledwie dziesięciu największych miastach oraz ich okręgach municypalnych mieszka obecnie (2006 r.) ponad $130 \mathrm{mln}$ Chińczyków, co stanowi ok. $10 \%$ populacji państwa. Największą liczbę mieszkańców skupia wschodnia część kraju. Kolejne milionowe miasta wyrastają tu w niewiarygodnym tempie. Szczególną uwagę - ze względu na niespotykaną kumulację ludności - należy zwrócić na region południowy, obejmujący Hongkong, Shenzhen i Kanton wraz z dużymi miastami prowincji Guangdong. Ważnym ośrodkiem stała się również aglomeracja Szanghaju oraz inne miasta regionu wschodniego, takie jak Nankin, Hangzhou, Ningbo czy Suzhou. Na północy zaś dominują przede wszystkim Pekin i Tianjin. Największym okręgiem municypalnym ChRL jest położony w środkowych Chinach „kolos” - Chongqing $^{6}$, który zamieszkiwany jest obecnie przez ponad $32 \mathrm{mln}$ mieszkańców.

Duże ośrodki miejskie wchłaniają najliczniejsze rzesze pracowników migracyjnych, a ponieważ leżą zazwyczaj $\mathrm{w}$ granicach specjalnych stref ekonomicznych - przyciagają liczne inwestycje. Są tym samym największym beneficjentem reform systemowych, przede wszystkim zaś - otwarcia na handel z zagranicą. Największe chińskie miasto, Szanghaj, liczy niespełna 10 mln mieszkańców, jednak brany pod uwage wraz z całym okręiem municypalnym - grubo ponad $17 \mathrm{mln}^{7}$. W 2000 r. migranci zarobkowi w okręgu miejskim Szanghaju stanowili grupę licząca ponad $4 \mathrm{mln}$ osób; szacuje się, iż obecnie liczebność jej przekroczyła $5 \mathrm{mln}$ osób, a więc stanowi ona ponad $25 \%$ populacji tej metropolii.

Tabela 1. Największe chińskie miasta (dane z lat 2000-2006)

\begin{tabular}{|l|c|c|}
\hline \multicolumn{1}{|c|}{ Nazwa } & $\begin{array}{c}\text { Liczba mieszkańców } \\
\text { w mln (miasto) }\end{array}$ & $\begin{array}{c}\text { Liczba mieszkańców } \\
\text { w mln (okręg miejski) }\end{array}$ \\
\hline Szanghaj & $9,838^{b}$ & $17,780^{d}$ \\
\hline Pekin & $7,500^{c}$ & $15,380^{d}$ \\
\hline Hongkong $^{d}$ & 7,041 & 7,041 \\
\hline Kanton $^{a}$ & 6,561 & 12,600 \\
\hline Harbin $^{d}$ & 4,642 & 9,462 \\
\hline Tianjin $^{c}$ & 4,345 & 10,240 \\
\hline Chongqing $^{d}$ & 4,000 & 31,442 \\
\hline Wuhan $^{d}$ & 3,958 & 9,100 \\
\hline Chengdu $^{d}$ & 3,900 & 10,820 \\
\hline Shenyang $^{d}$ & 3,453 & 7,200 \\
\hline
\end{tabular}

Objaśnienia: ${ }^{a}$ - cenzus z 2000 r.; ${ }^{b}$ - dane z 2001 r.; ${ }^{c}$ - dane z 2004 r.; ${ }^{d}$ - dane szacunkowe z 2005 r.

\footnotetext{
${ }^{6}$ Powierzchnia okręgu miejskiego Chongqing wynosi ok. $82.000 \mathrm{~km}^{2}$.

${ }^{7}$ Dane na 2006 r.
} 


\section{Ekonomiczne uwarunkowania polaryzacji społeczeństwa chińskiego}

Uprzywilejowana pozycja ekonomiczna rozwiniętej, nadmorskiej części Chin jest efektem konsekwentnej realizacji założeń gospodarczych, formułowanych przez Deng Xiaopinga od końca lat siedemdziesiątych XX w. Wielokrotnie powtarzał on, że aby w kraju tak wielkim jak Chiny podnieść poziom życia ogółu ludności, trzeba najpierw pozwolić na bogacenie się jej części:

Zezwalamy, żeby najpierw pewne regiony i niektórzy ludzie osiagnnęli zamożność, by tą drogą stopniowo doprowadzić w końcu do powszechnego dobrobytu ${ }^{8}$.

[...] opowiadamy się za tym, aby część ludzi szybciej osiągnęła stan zamożności; zakładamy, że dopomogą oni innym w osiągnięciu dostatku, tak, aby stał się on wspólnym dobrem9.

Deng Xiaoping wielokrotnie podkreślał, że nie chce, aby w Chinach doszło do trwałej dywersyfikacji społeczeństwa, jednocześnie zachęcał jednak do sprowadzania w obręb regionów rozwijających się taniej siły roboczej z głębi kraju. Kontraktowy system pracy miał, jego zdaniem, podnieść efektywność produkcji, czyniąc migrację zarobkową czynnikiem wysoce pozytywnym dla gospodarki ${ }^{10}$. Migracje wewnętrzne należy tym samym uznać za jeden $\mathrm{z}$ najważniejszych czynników wysokiego wzrostu PKB Chin w ostatnich dekadach. To, co pod koniec XX stulecia pozwoliło Chinom na dokonanie skoku cywilizacyjnego, zrewolucjonizowało międzynarodowe stosunki gospodarcze, a przywódcy chińskiemu przyniosło wyrazy uznania ze strony części zachodniego świata ${ }^{11}$, jest źródłem największego problemu społecznego Chin pierwszej połowy XXI w. - rosnącej polaryzacji społeczeństwa. Współczynnik Giniego, będący jednym z podstawowych wskaźników dysproporcji w rozkładzie dochodów, w latach 1978-2000 wzrósł w Chinach z 0.21 do 0.35 na terenach wiejskich oraz z 0.16 do 0.32 na terenach miejskich ${ }^{12}$. Chiny stały się więc jednym z najbardziej zróżnicowanych społeczeństw świata. Na wspomniane czynniki gospodarcze i polityczne nakładają się także uwarunkowania geograficzne, historyczne oraz etniczne ${ }^{13}$. Warto zwrócić uwagę m.in. na to, że regiony najuboższe i najbardziej zacofane są w większości (lub w znacznej) mierze zamieszkiwane przez mniejszości etniczne.

${ }^{8} \mathrm{D}$ e n g X i a o p in g, Należy zajmować wyraźne stanowisko $w$ walce z burżuazyjna liberalizacja, 30.12.1986, [w:] i d e m, Chińska droga do socjalizmu, przeł. Z. Góralczyk, J. Rowiński, R. M. Sławiński, B. Zakrzewski, Książka i Wiedza, Warszawa 1988, s. 341.

${ }^{9} \mathrm{D}$ e ng Xiaoping, Jedność możliwa jest tylko na gruncie ideatów $i$ dyscypliny, 7.03.1985, ibidem, s. 307.

${ }^{10} \mathrm{Deng} \mathrm{X}$ i a o p ing, $O$ kwestii specjalnych stref ekonomicznych $i$ zwiększenia liczby miast otwartych, 24.02.1984, ibidem, s. 277.

${ }^{11}$ Magazyn „Time” dwukrotnie przyznawał mu tytuł Człowieka Roku (w 1978 i 1985 r.).

${ }^{12}$ P. H u a n g, F. N. P i e k e, op. cit., s. 27.

${ }^{13} \mathrm{Z}$ tym ostatnim wiąże się odmienność w wielopoziomowej polityce, prowadzonej wobec prowincji rdzennie , ,chińskich”, tj. zamieszkiwanych przez ludność Han od prowincji o znaczącym udziale mniejszości etnicznych. 


\subsection{Poziom PKB oraz akumulacja dóbr trwałych - zróżnicowanie regionalne}

Jednym z narzędzi służących badaniu zróżnicowania rozwoju gospodarczego poszczególnych regionów Chin może być analiza poziomu produktu krajowego brutto w przeliczeniu na 1 mieszkańca na poziomie prowincji. W $2002 \mathrm{r}$. wynosił on średnio ok. 1,35 tys. USD, czyli 10,56 tys. yuanów ${ }^{14}$. Nie jest to wynik imponujący, a mimo to i tak w 17 prowincjach wskaźnik ten kształtuje się znacznie poniżej średniej krajowej. PKB w przeliczeniu na 1 mieszkańca w Szanghaju (55,31 tys. RMB w 2004 r.) jest ponad 13 razy wyższy niż w prowincji Guizhou (4,13 tys. RMB). Warto dodać w tym miejscu, iż Hongkong przewyższa pod tym względem Szanghaj ponad trzykrotnie (ok. 184,398 tys. RMB w 2004 r.) $)^{15}$. Ekonomiści zauważają, że zróżnicowanie regionalne pod względem poziomu PKB w przeliczeniu na 1 mieszkańca w poszczególnych prowincjach ,,jest dziś tak uderzające, iż Chiny sprawiają wrażenie kontynentu składającego się $\mathrm{z}$ mieszanki średnio zamożnych państw przemysłowych oraz jednych z najuboższych państw świata"16.

Tabela 2. Wysokość PKB w przeliczeniu na 1 mieszkańca (2004)

\begin{tabular}{|l|c|l|c|}
\hline \multicolumn{1}{|c|}{ Nazwa } & $\begin{array}{c}\text { Wysokość PKB } \\
\text { w przeliczeniu na } \\
\text { mieszkańca (RMB) }\end{array}$ & Nazwa & $\begin{array}{c}\text { Wysokość PKB } \\
\text { w przeliczeniu na } \\
\text { mieszkańca (RMB) }\end{array}$ \\
\hline Guizhou & 4,125 & Jilin & 10,932 \\
\hline Gansu & 5,970 & Xinjiang & 11,199 \\
\hline Yunnan & 6,733 & Mongolia Wewnętrzna & 11,305 \\
\hline Guangxi & 7,196 & Hebei & 12,918 \\
\hline Shaanxi & 7,757 & Heilongjiang & 13,897 \\
\hline Anhui & 7,768 & Liaoning & 16,297 \\
\hline Tybet & 7,779 & Szantung & 16,925 \\
\hline Ningxia & 7,880 & Fujian & 17,218 \\
\hline Syczuan & 8,113 & Guangdong & 19,707 \\
\hline Jiangxi & 8,189 & Jiangsu & 20,705 \\
\hline Qinghai & 8,606 & Zhejiang & 23,942 \\
\hline Hunan & 9,117 & Tianjin & 31,550 \\
\hline Shanxi & 9,150 & Pekin & 37,058 \\
\hline Hajnan & 9,450 & Szanghaj & 55,307 \\
\hline Henan & 9,470 & & \\
\hline Chongqing & 9,608 & & \\
\hline Hubei & 10,500 & & $\mathbf{1 8 4 , 3 9 8}$ \\
\hline Średnia krajowa & $\mathbf{1 0 , 5 6 1}$ & Hongkong & \\
\hline
\end{tabular}

Źródło: opracowanie własne na podstawie National Bureau of Statistics of China, http://www.stats.gov.cn/tjsj/ndsj/2005/indexeh.htm (stan z 12.10.2006).

${ }^{14}$ National Bureau of Statistics of China, http://www.stats.gov.cn/tjsj/ndsj/2005/indexeh.htm (stan z 13.11.2006).

${ }^{15}$ Ibidem.

${ }^{16}$ A. L i n d b e c k, Economic-Social Interaction during China's Transition, Keynote speech at Chinese Economists' Society Congress, Shanghai 2006, s. 10. 


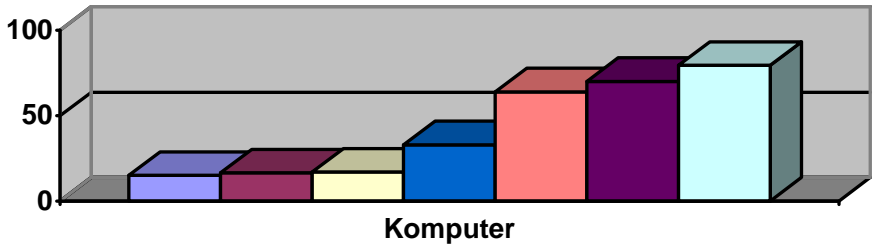

\section{$\square$ Ningxia $\square$ Qinghai $\square$ Tybet $\square$ Średnia krajowa $\square$ Guangdong $\square$ Shanghai $\square$ Beijing}

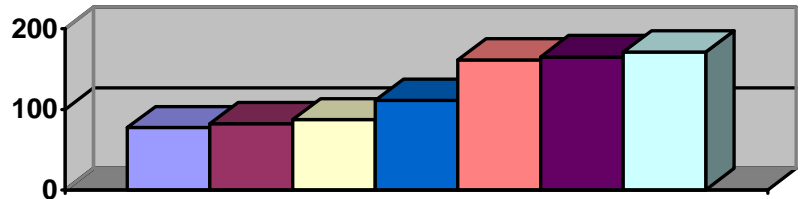

Telefon komórkowy

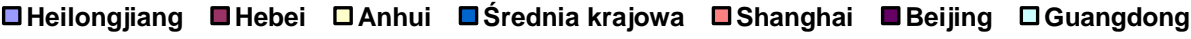

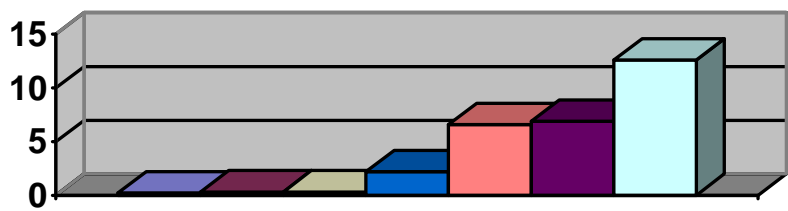

Samochód

\begin{tabular}{|lllllll}
\hline$\square$ Gansu & 口Hubei & 口Chongqing & QŚrednia krajowa & QGuangdong & QYunnan & $\square$
\end{tabular}

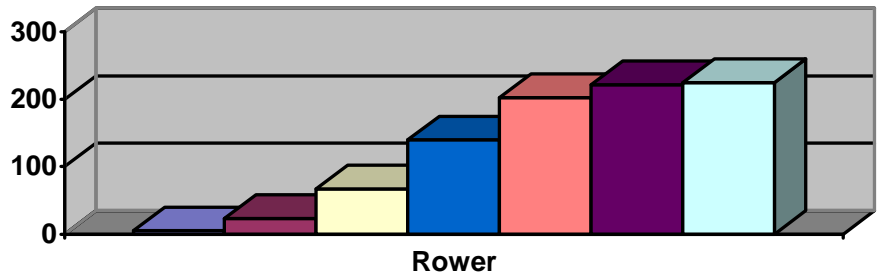

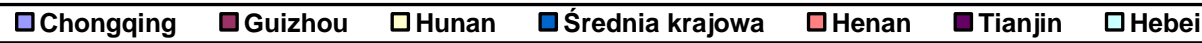

Rys. 4. Ilość dóbr trwałych przypadających na 100 gospodarstw domowych (2004)

Źródło: opracowanie własne na podstawie National Bureau of Statistics of China, http://www.stats.gov.cn/tjsj/ndsj/2005/indexeh.htm (stan z 12.10.2006). 
Geograficzne zróżnicowanie rozwoju Chin przekłada się wyraźnie na akumulację środków oraz poziom życia mieszkańców poszczególnych regionów. Analiza dostępu mieszkańców poszczególnych prowincji do wybranych dóbr trwałych pozwala na sformułowanie pewnych wniosków. O ile takie dobra jak telefon komórkowy czy komputer są w zamożniejszych prowincjach wschodnich normalnym narzędziem pracy i komunikacji, w mniej rozwiniętych regionach pozostają dobrem luksusowym. $\mathrm{Z}$ danych Chińskiego Instytutu Statystycznego wynika, że w 2004 r. 80\% gospodarstw domowych w Pekinie dysponowało własnym komputerem ${ }^{17}$. W tym samym czasie w prowincjach Ningxia, Qinghai czy Tybet odsetek ten nie przekraczał 17\%. Wymowne rozbieżności zaobserwować można na rynku motoryzacyjnym. W dużych miastach samochody osobowe są codziennym środkiem transportu dla coraz większej liczby osób, natomiast na wsi, zwłaszcza w głębi kraju, są one zarezerwowane głównie dla lokalnych dygnitarzy oraz zamożnych przedsiębiorców.

\subsection{Migracje wewnętrzne w Chinach}

Mieszkańcy najsłabiej rozwiniętych regionów i prowincji mają utrudniony dostęp do służby zdrowa i edukacji. Brak infrastruktury lub słaby jej stan, nieatrakcyjne położenie i niesprzyjające warunki geograficzne, brak programów przyciagających inwestorów, brak profesjonalnej kadry, w końcu - w przypadku regionów zamieszkiwanych $\mathrm{w}$ znacznym lub przeważającym stopniu przez mniejszości etniczne - bariery kulturowe i językowe sprawiają, że ogromne dysproporcje występują także na rynku pracy. Zacofane regiony na zachodzie i w centralnych Chinach nie przyciagaja, co zrozumiałe, tylu inwestycji, co prowincje wschodnie, nie mogą więc zaoferować wystarczającej liczby miejsc pracy. Według oficjalnych danych, bezrobocie w miastach wynosi obecnie ok. $4,2 \%{ }^{18}$, można jednak przypuszczać, iż w rzeczywistości wskaźnik ten jest wyższy. Choć nadwyżkę siły roboczej na wsi wciąż szacuje się na 100, a nawet $150 \mathrm{mln}$ osób, prognozy przewidują, że już na początku drugiej dekady XXI w. Chiny będą musiały zmierzyć się z poważnym problemem braku rąk do pracy. Migrację ludności wiejskiej do miast w poszukiwaniu pracy przez lata skutecznie blokował rząd w Pekinie. Hukou w latach osiemdziesiątych i dziewięćdziesiątych XX w. ${ }^{19}$, a także zniesienie systemu racjonowania żywności wywołało gwałtowną falę migracji zarobkowej przyczyniły się do zwiększenia konkurencyjności chińskiej gospodarki i dały nadzieję milionom ubogich Chińczyków na

\section{${ }^{17}$ Ibidem.}

${ }^{18}$ Ibidem.

${ }^{19}$ Za pierwszy akt prawny, dopuszczający ograniczoną migrację, należy uznać wytyczne rządowe z 1 kwietnia 1984 r., pozwalające rolnikom na przekraczanie granic miast pod warunkiem posiadania wystarczającego wyżywienia. Por.: P. H u a n g, F. N. P i e k e, op. cit., s. 32. 
znalezienie pozarolniczego źródła utrzymania. Ci źle opłacani i słabo wykształceni $^{20}$ pracownicy, pochodzący ze wsi i małych miasteczek, stanowią obecnie ponad $10 \%$ społeczeństwa chińskiego, a dokładniej - nawet $150 \mathrm{mln}$ osób. Oznacza to, że w miastach pracuje i mieszka obecnie niemal 1/4 populacji wiejskiej. Od początku lat dziewięćdziesiątych XX w. liczba pracowników migracyjnych wzrosła o ok. $60 \mathrm{mln}^{21}$.

Rząd chiński za migrantów (qianyi) uznaje oficjalnie wyłącznie osoby, które, zmieniając miejsce zamieszkania, dokonały odpowiedniej modyfikacji swego statusu hukou. Na status hukou składają dwa podstawowe czynniki, a mianowicie: miejsce zameldowania (hukou suzaidi) oraz typ zameldowania (hukou leibie), dzielący się ogólnie na rolniczy i pozarolniczy. Możliwości oficjalnej i trwałej zmiany statusu hukou są mocno ograniczone ${ }^{22}$.

Pozostałe grupy migrantów nazywane są w Chinach tymczasowymi migrantami $^{23}$, ptywajacq populacja (liudong renkou), pracownikami wiejskimi (mingong), czarnymi ludźmi (heiren), czy pracujacymi siostrami i braćmi (dagong jie, dagong zai). Można wyróżnić w tym miejscu osoby, które mają w dokumentach wpis o tymczasowej zmianie miejsca zamieszkania, a także osoby, których dokumenty o takiej zmianie nie wspominaja.

„Pływająca populacja” boryka się z wieloma problemami. Wynikający z nieposiadania miejskiego hukou brak dostępu do opieki zdrowotnej i socjalnej, brak (lub silne ograniczenie) możliwości kształcenia towarzyszących rodzicom dzieci, fatalne warunki mieszkaniowe, łamanie prawa pracy - to tylko nieliczne $\mathrm{z}$ nich. Migranci zarobkowi mieszkają zazwyczaj w przyfabrycznych internatach, w wieloosobowych pokojach, $\mathrm{z}$ bardzo słabym zapleczem sanitarnym. Pracują po kilkanaście godzin dziennie, przez sześć lub siedem dni w tygodniu, a swe rodziny widują wyłącznie podczas Chińskiego Nowego Roku, stanowiącego jedyną okazję do wyjazdu w rodzinne strony. Pracownicy migracyjni

${ }^{20}$ Należy w tym miejscu zaznaczyć, że średni poziom wykształcenia migrantów jest wyższy od poziomu wykształcenia tych osób, które, mając identyczne korzenie, na migrację się nie decydują. Por. m.in. P. H u a n g, F. N. P i e k e, op. cit.

${ }^{21}$ Young female migrant workers in China in need of reproductive health and services, ,Social Science Research Policy Briefs", S. 2, No. 2, May 2002, http://www.who.int/reproductivehealth/hrp/Policy_briefs/pb5.pdf (stan z 20.10.2006).

${ }^{22}$ Por.: X. W u, D. J. T r e i m a n, The Household Registration System and social stratification in China: 1955-1996, California Center for Population Research, University of California, Los Angeles 2002.

${ }^{23}$ Chińskie władze nie stworzyły jednolitej definicji „migrantów tymczasowych”. Definicji stosowanych w chińskich badaniach społecznych jest kilka. Mianem „migrantów tymczasowych” określane są zazwyczaj osoby przebywające w czasie przeprowadzania badania poza swym oficjalnym miejscem zamieszkania, choć różnie definiują okres, jaki osoby te muszą spędzić poza miejscem określonym przez ich dokument hukou, by zostały zaliczone do tej grupy. Por.: Z. Li a ng, The Age of Migration in China, „Population and Development Review”, wrzesień 2001, No. 27(3), s. 499-524. 
określani są często jako grupa „trzech nie”, tj. nie posiadająca dowodów osobistych, prawa do pobytu i prawa do pracy na terenie miasta. Ci spośród nich, którzy chcą posłać swe dzieci do publicznej szkoły, muszą się liczyć z koniecznością płacenia czesnego kilkakrotnie wyższego od tego płaconego przez rodziców posiadających miejscowe $h u k o u^{24}$. Warto zaznaczyć, że liczbę dzieci migrantów zarobkowych, mieszkających w samej tylko „nadmorskiej” części Chin, szacuje się obecnie na ok. $20 \mathrm{mln}^{25}$.

Wielu migrantów boryka się z problemem niewypłacania wynagrodzeń (w 2006 r. wartość niewypłaconych pensji mogła wynosić w skali kraju nawet 100 mld yuanów ${ }^{26}$ ), wszyscy zaś - z problemem niskich zarobków. Wysokość wynagrodzenia pracowników migracyjnych zależy od wielkości oraz specjalizacji zatrudniającej ich firmy i jej pozycji na rynku, od wielkości miejscowości oraz od liczby przepracowanych przez robotnika godzin. Średnie miesięczne zarobki wahają się od $300^{27}$ do ok. $1200^{28}$ yuanów. Lepiej opłacani są robotnicy mający przygotowanie techniczne, a także ci, którzy od lat pozostają wierni firmie. W najlepszej sytuacji znajdują się pracownicy firm zagranicznych oraz joint-venture. Warto podkreślić, że firmy zatrudniające pracowników migracyjnych borykają się obecnie z problemem znacznego odpływu robotników. W ciągu roku rotacji ulega średnio $1 / 3$ siły roboczej. Często robotnicy po prostu nie wracają do fabryk po zakończeniu Chińskiego Nowego Roku. Prasa chińska donosi, iż wielu byłych pracowników migracyjnych po odłożeniu odpowiednich środków finansowych inwestuje we własną działalność gospodarczą ${ }^{29}$. Przypadki takie należą jednak do rzadkości. Zdecydowana większość spośród tych, którzy nie wracają do fabryk, bądź znajduje nową pracę, bądź - rozczarowana życiem w mieście - postanawia powrócić do rodzinnej miejscowości.

W skali kraju w grupie pracowników migracyjnych zdecydowanie dominują mężczyźni. Wyjątek stanowi prowincja Guangdong wraz ze specjalną strefą ekonomiczną w Shenzhen, gdzie ponad $60 \%$ pracowników migracyjnych stanowią kobiety, pracujące głównie w firmach produkujących odzież, obuwie, zabawki itp. Kobiety pracują także w restauracjach lub w charakterze pomocy

${ }^{24}$ Więcej na ten temat w części poświęconej systemowi edukacji.

${ }^{25}$ H. W. F r e n c h, China Strains to Fit Migrants Into Mainstream Classes, ,The New York Times", 25.01.2007.

${ }^{26}$ Szacunki Ogólnochińskiej Federacji Związków Zawodowych, za: The Canadian Broadcasting Corporation, http://cbc.radio-canada.ca/home.asp (stan z 01.10.2006).

${ }^{27}$ Rural-urban income gap contiues to widen, „China Daily”, 17.04.2006, za: M. T u ñ ó n, Internal Labour Migration in China: Features and Responses, International Labour Organization, 2006, s. 12.

${ }^{28}$ Maksymalna wysokość zarobków robotników migracyjnych w fabrykach tekstylnych w okręgach municypalnych miast Suzhou (prow. Jiangsu) oraz Huzhou (prow. Zhejiang) w 2006 r. Dane zgromadzone przez autorkę.

${ }^{29}$ Chinese migrant workers succeed after returning home, „People's Daily”, 10.03.2005, http://english.people.com.cn/200503/10/eng20050310_176276.html ( $\operatorname{stan}$ z 1.10.2006). 
domowych, inne parają się prostytucją. Robotnicy migracyjni to głównie ludzie młodzi - niemal $86 \%$ nie przekroczyło 40 roku życia ${ }^{30}$. W tym kontekście nie powinna dziwić tendencja do częstej zmiany miejsca pracy - nie bez znaczenia jest tu duża mobilność młodych ludzi oraz ciekawość świata. Prawie połowa pracowników migracyjnych ma mniej niż 25 lat, $60 \%$ przebywa poza granicami rodzimej prowincji ${ }^{31}$. Największa grupa migrantów pracuje w prowincji Guangdong, a także w Szanghaju, Pekinie i Tianjinie ${ }^{32}$. W fabrykach stanowią oni zdecydowaną większość pracowników fizycznych ${ }^{33}$.

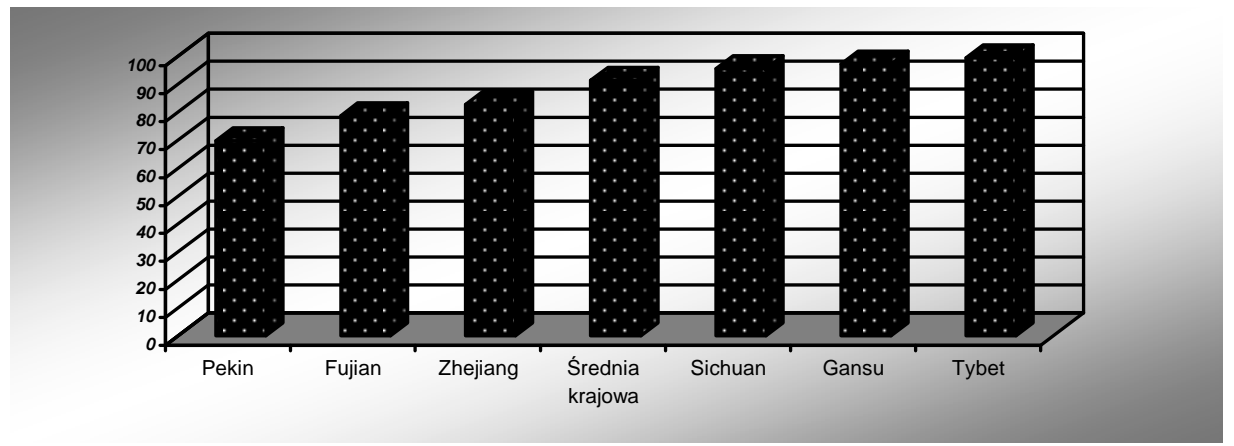

Rys. 5. Odsetek osób mieszkających w danym regionie na podstawie stałego zameldowania (2004)

Źródło: opracowanie własne na podstawie National Bureau of Statistics of China, http://www.stats.gov.cn/tjsj/ndsj/2005/indexeh.htm (stan z 12.10.2006).

Migranci spotykają się często z niechęcią ze strony miejscowej ludności. Funkcjonuje stereotyp przedstawiający ich jako niezaradna, niedbającą o higienę masę, niemoralną i dopuszczającą się wielu przestępstw. Trzeba jednak podkreślić, że media chętnie stają w ich obronie, a temat pracowników migracyjnych jest w nich stale obecny. Są przedstawiani bądź jako ofiary (wypadków, wykorzystywania przez pracodawców), bądź jako bohaterowie, którzy z odwagą opuszczają dom i rodzinę po to, by po latach ciężkiej pracy wrócić do rodzinnej prowincji, gdzie pomagają krewnym, budują dom, a nawet zakładają własną firmę.

Byli pracownicy migracyjni lub ci, którym pracy w mieście znaleźć się nie udało, stanowią znaczną część chińskich bezdomnych. Bezdomność pozostaje w Chinach tematem tabu, brak rzetelnych danych, mówiących o tym, ile osób

${ }^{30}$ Dane za: China had 113.9 million migrant workers in 2003, Agencja Xinhua, 15.05.2004. http://www.chinadaily.com.cn/english/doc/2004-05/15/content_330991.htm (stan z 18.10.2006).

${ }^{31}$ Ibidem.

${ }^{32}$ K. W. C h a n, T. Li u, Y. Y a n g, Hukou and Non-hukou Migrations in China: Comparisons and Contrasts, „International Journal of Population Geography” 1999, No. 5, s. 436.

${ }^{33}$ Niejednokrotnie stanowią 80-90\% wszystkich robotników. Informacje zgromadzone przez autorkę podczas rozmów z kadrą fabryk tekstylnych w okręgach municypalnych miast Suzhou (prow. Jiangsu) oraz Huzhou (prow. Zhejiang), 2006 r. 
dotkniętych jest tym problemem. Z zainteresowaniem rządu spotkały się natomiast bezdomne dzieci, których liczbę w Chinach szacuje się oficjalnie na ok. 150 tys. ${ }^{34}$ Wspólnie z UNICEF-em władze chińskie założyły w ostatnich latach sieć schronisk dla dzieci, zapewniając im podstawową opiekę oraz dostęp do edukacji. Placówki te pomogły jednak do tej pory zaledwie ok. 10 tys. nieletnich ${ }^{35}$.

\section{Społeczne skutki dywersyfikacji społeczeństwa chińskiego}

Ze zjawiskami świadczącymi o polaryzacji współczesnego społeczeństwa chińskiego (a przede wszystkim o bolesnych jej skutkach) można się zetknąć na wielu polach, takich jak system edukacji lub opieki zdrowotnej. To na tych płaszczyznach dochodzi do najbardziej bulwersujących przypadków naruszeń zasady równości obywateli wobec prawa.

\subsection{System edukacji}

Chińska konstytucja z 1982 r. przewiduje obowiązek szkolny na poziomie podstawowym ${ }^{36}$. Premier Wen Jiabao zapowiedział w 2005 r. wprowadzenie do 2010 r. darmowej 9-letniej edukacji dla dzieci ze wsi (zasada ,jiu nian yi wu jiao yu”, czyli „9 lat darmowej nauki”), a do roku 2015 - dla wszystkich dzieci chińskich $^{37}$. Teoretycznie państwo nie ma prawa żądać jakichkolwiek opłat za dostęp do obowiązkowej edukacji ${ }^{38}$. W praktyce jednak rodzice uczniów muszą pokrywać czesne, przeznaczane m.in. na zakup książek i pomocy naukowych. Szkolnictwo stale cierpi z powodu niewystarczającego dofinansowania ze strony państwa. W najgorszej sytuacji znajdują się placówki z najuboższych regionów. Niektóre spośród nich próbują poprawić dramatyczną sytuację ekonomiczną poprzez zmuszanie uczniów do wykonywania dodatkowych prac na rzecz zewnętrznych zleceniodawców. W 2001 r. w szkole we wsi Fanglin (prowincja Jiangxi) co najmniej 38 uczniów zginęło na skutek wybuchu sztucznych ogni, do produkcji których byli oni zmuszani, prawdopodobnie podczas przerwy obiadowej lub po zajęciach. W wielu szkołach uczniowie, zwłaszcza ci zamiejscowi, mieszkający w internatach, przynoszą ze sobą żywność, głównie ryż, przezna-

\footnotetext{
${ }^{34}$ Shelters needed for homeless children, „China Daily”, 25.03.2004, http://www.chinadaily. com.cn/english/doc/2004-03/25/content_317857.htm (stan z 15.10.2006).

${ }^{35}$ Homeless aid system formed in China, „People's Daily”, 9.08.2005, http://english.people. com.cn/200508/09/eng20050809_201235.html (stan z 15.10.2006).

${ }^{36}$ Art. 9 Konstytucji Chińskiej Republiki Ludowej, przyjętej 4 grudnia 1982 r.

${ }^{37}$ Rich-poor education gap to be addressed, 30.11.2005, China Education Research Network, http://www.edu.cn/compulsory_1424/20060323/t20060323_151968.shtml (stan z 5.11.2006).

${ }^{38}$ Zgodnie z literą prawa o szkolnictwie obowiązkowym, przyjętego rozporządzeniem Prezydenta ChRL 12.04.1986.
} 
czany później na skromne posiłki dla dzieci, a często również dla nauczycieli. Roczne czesne w szkołach podstawowych wynosi średnio ok. kilkaset yuanów, w szkołach średnich - ok. tysiąca yuanów, a na uczelniach wyższych kilka tysięcy yuanów ${ }^{39}$. Wysokość czesnego zależy nie tylko od szczebla szkoły, lecz także od wielkości miejscowości i renomy placówki. Większość rodzin nie może pozwolić sobie na pełne wykształcenie dzieci. Nie należy do rzadkości sytuacja, gdy rodzice muszą zrezygnować z edukacji jednego ze swych dzieci na rzecz drugiego. Najczęściej poszkodowanymi w tego typu wyborach stają się dziewczynki. W rezultacie kobiety dominują wśród osób niepiśmiennych. O ile w szkołach podstawowych dziewczynki minimalnie przewyższają pod względem liczebności chłopców, o tyle szkoły średnie oraz wyższe zdecydowanie częściej kończą chłopcy. W latach 1993-1999, w ramach prowadzonego przez Ogólnochińską Federację Kobiet oraz Fundusz Chińskich Dzieci i Młodzieży programu „Wiosenny Pąk”, zebrano w kraju ok. 220 mln yuanów, umożliwiajace powrót do szkół ok. 900 tys. dziewcząt, które uprzednio, z powodu biedy musiały zrezygnować z edukacji ${ }^{40}$.

W roku 2004 struktura wykształcenia Chińczyków powyżej 6 roku życia przedstawiała się w następujący sposób ${ }^{41}$ :

- osób z wykształceniem podstawowym (wraz z uczniami szkół podstawowych) - $381 \mathrm{mln}$, czyli ok. $32 \%$ populacji;

- osób z wykształceniem średnim pierwszego i drugiego stopnia - ok. 621 mln, czyli ok. 53\% populacji;

- osób z wykształceniem wyższym pierwszego i drugiego stopnia - ok. 68 mln, czyli ok. 6\% ogólnej liczby mieszkańców.

Tabela 3. Struktura wykształcenia Chińczyków (2004) (osoby powyżej 6 roku życia)

\begin{tabular}{|l|l|r|r|c|c|}
\hline \multicolumn{1}{|c|}{ Wyszczególnienie } & & Kraj & Tybet & Szantung & Pekin \\
\hline Całkowita liczba ludności & mln. osób & 1178,00 & 2,443 & 83,319 & 13,767 \\
& & & & & \\
\hline \multirow{2}{*}{ Wykształcenie podstawowe } & mln. osób & 381,371 & 1,146 & 22,840 & 2,003 \\
\cline { 2 - 6 } & proc. & $32,4 \%$ & $46,9 \%$ & $27,4 \%$ & $14,6 \%$ \\
\hline \multirow{2}{*}{$\begin{array}{l}\text { Wykształcenie średnie } \\
\text { I i II stopnia }\end{array}$} & mln. osób & 620,579 & 0,365 & 46,393 & 7,893 \\
\cline { 2 - 6 } & proc. & $52,7 \%$ & $14,9 \%$ & $55,7 \%$ & $57,3 \%$ \\
\hline \multirow{2}{*}{$\begin{array}{l}\text { Wykształcenie wyższe } \\
\text { I i II stopnia }\end{array}$} & mln. osób & 67,945 & 0,023 & 4,571 & 3,289 \\
\cline { 2 - 6 } & proc. & $5,8 \%$ & $0,9 \%$ & $5,5 \%$ & $23,9 \%$ \\
\hline
\end{tabular}

${ }^{39}$ Przeciętna wysokość czesnego w szkołach różnego szczebla w mieście Suzhou, prow. Jiangsu, w roku 2006. Dane zgromadzone przez autorkę.

${ }^{40}$ 35,000 Gansu Girls Return to Schools, China Education Research Network, 01.01.2001, http://www.edu.cn/bud_1423/20060323/t20060323_3911.shtml (stan z 28.10.2006).

${ }^{41}$ National Bureau of Statistics of China, http://www.stats.gov.cn/tjsj/ndsj/2005/indexeh.htm (stan z 10.10.2006). 


\section{Średnia krajowa}

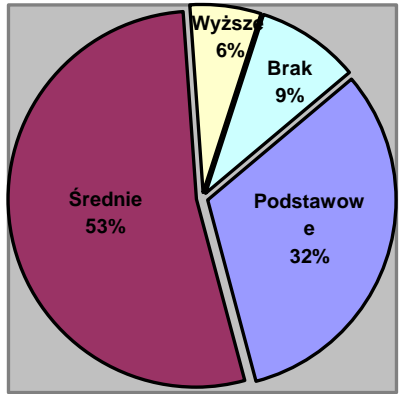

\section{Pekin (okręg municypalny)}

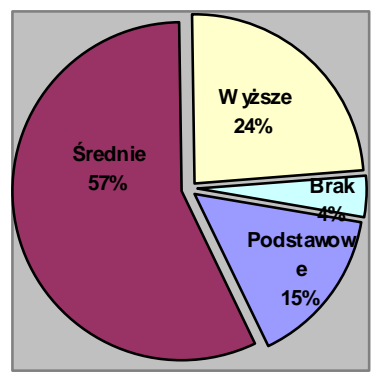

Tybet

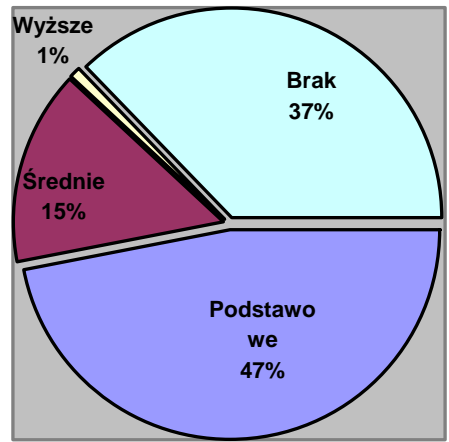

Ź r ó d ł o: opracowanie własne na podstawie National Bureau of Statistics of China, http://www.stats.gov.cn/tjsj/ndsj/2005/indexeh.htm (stan z 10.10.2006).

Zjawiskiem stosunkowo nowym w komunistycznych Chinach jest szkolnictwo prywatne. Liczba niepublicznych przedszkoli, szkół podstawowych, średnich, zawodowych i wyższych rośnie w błyskawicznym tempie. W $2001 \mathrm{r}$. w ponad 56 tys. placówek prywatnych uczyło się ok. 9,22 mln dzieci i młodzieży $^{42}$. Prawo do nadawania tytułu magistra otrzymało do tego czasu 436 prywatnych szkół wyższych, czyli 1/3 wszystkich istniejących. W 2004 r. liczba placówek niepublicznych wzrosła w Chinach do 70 tys., a liczba ich uczniów przekroczyła $14 \mathrm{mln}^{43}$. Władze chińskie uważają tworzenie szkół prywatnych (w tym także tych powstających w kooperacji z placówkami zagranicz-

${ }^{42} \mathrm{Z}$ h a n g Y u, Private Education in China: Issues and Prospects, „Perspectives”, 31.12.2003, No. 4/4, Overseas Young Chinese Forum, www.oycf.org/Perspectives/23_123103/3._ZhangYu. pdf (stan z 16.10.2006).

${ }^{43}$ China has more than 70,000 private schools, „People's Daily”, 26.03.2004, http://english. peopledaily.com.cn/200403/26/eng20040326_138601.shtml, (stan z 28.12.2006). 
nymi) za zjawisko pozytywne. Odciążają one szkolnictwo publiczne i są źródłem dodatkowych dochodów dla państwa. Placówki zakładane we współpracy z instytucjami zagranicznymi są, zdaniem rządu, ,zjawiskiem pozytywnym dla dobra publicznego i elementem składowym chińskiego systemu edukacji”, Wysokość czesnego w szkołach prywatnych zależy od wielu czynników, takich jak ich prestiż, zaplecze edukacyjne i możliwość kontynuowania edukacji za granicą (każdego roku na studia zagraniczne wyjeżdża 20-25 tys. Chińczyków, do kraju powraca zaledwie $1 / 3$ tej liczby ${ }^{45}$ ). Semestr nauki na poziomie podstawowym w szkołach prywatnych o wysokim standardzie wynosi w Szanghaju ${ }^{46}$ od trzydziestu kilku do ok. stu tysięcy yuanów.

Istnieje też inna strona szkolnictwa niepublicznego. W Pekinie, Szanghaju czy Kantonie, gdzie liczba pracowników migracyjnych jest duża, powstają szkoły prywatne drugiej kategorii. Uczą się w nich dzieci migrantów, pozbawione miejscowego hukou, a więc i prawa do nauki w miejscowych szkołach na zasadach przysługujących ,prawowitym” uczniom. W 2003 r. władze nakazały administracji lokalnej zapewnienie dostępu do edukacji wszystkim dzieciom, także dzieciom pracowników migracyjnych ${ }^{47}$. W efekcie lokalne władze, chcąc wywiązać się z obowiązku, zamykają ${ }^{48}$ coraz większą liczbę prywatnych szkół dla migrantów, nie zapewniając miejsc w placówkach publicznych zdecydowanej większości uczniów.

\subsection{Zjawisko analfabetyzmu}

Analfabetyzm jest wielkim problemem współczesnych Chin. Dotyka on przede wszystkim mieszkańców prowincji najuboższych, zamieszkanych głównie przez mniejszości etniczne, takich jak Qinghai, Tybet, Yunnan itd. Walkę $\mathrm{z}$ analfabetyzmem utrudnia, $\mathrm{z}$ jednej strony, słabe zaplecze edukacyjne (w tym kadrowe), a także pozostawiająca wiele do życzenia infrastruktura w najgorzej rozwiniętych prowincjach i okręgach, z drugiej zaś - migracje osób dotkniętych wspomnianym problemem oraz towarzyszących im dzieci.

\footnotetext{
${ }^{44}$ Regulations on Chinese-Foreign Cooperation in Running Schools, Ministerstwo Edukacji ChRL, http://www.moe.edu.cn/english/laws_r.htm, (stan z 19.02.2003).

${ }^{45}$ Number of Post Graduates and Students Studying Abroad, China Education and Research Network, 01.01.2001, http://www.edu.cn/education_1384/20060323/t20060323_4386.shtml (stan z 28.11.2006).

${ }^{46}$ Np. Shanghai American School, Shanghai High School, Concordia International School Shanghai.

${ }^{47}$ H. W. Fre n c h, op. cit.

${ }^{48}$ Bądź wykupują i zamieniają je w szkoły publiczne; za: H. W. F r e n c h, op. cit.
} 
Tabela 4. Analfabetyzm w Chinach (2004)

\begin{tabular}{|l|c|c|c|c|}
\hline Nazwa & $\begin{array}{c}\text { Analfabeci pow. } \\
\text { 15 roku życia } \\
(\mathrm{mln} . \text { os. })\end{array}$ & $\begin{array}{c}\text { Kobiety } \\
(\mathrm{w} \%)\end{array}$ & $\begin{array}{c}\text { Mężczyźni } \\
(\mathrm{w} \%)\end{array}$ & $\begin{array}{c}\text { Odsetek całej populacji } \\
\text { pow. 15 roku życia } \\
(\mathrm{w} \%)\end{array}$ \\
\hline Kraj & 104,324 & 71 & 29 & 10 \\
\hline Tybet & 0,873 & 63 & 37 & 44 \\
\hline Qinghai & 0,883 & 69 & 31 & 22 \\
\hline Liaoning & 1,543 & 76 & 24 & 4 \\
\hline Jilin & 0,874 & 66 & 34 & 13 \\
\hline Szantung & 9,274 & 73 & 27 & 4 \\
\hline
\end{tabular}

Źródło: opracowanie własne na podstawie National Bureau of Statistics of China, http://www.stats.gov.cn/tjsj/ndsj/2005/indexeh.htm (stan z 18.10.2006).

Oficjalne statystyki chińskie mówią o ponad $104 \mathrm{mln}$ analfabetów ${ }^{49}$ (2004 r.), co stanowi niemal $10 \%$ całej populacji. Warto jednak w tym miejscu wspomnieć, że u progu istnienia Chińskiej Republiki Ludowej niepiśmienni stanowili aż $80 \%$ społeczeństwa ${ }^{50}$. Obecnie prowincją o największej liczbie analfabetów, przekraczającej $9 \mathrm{mln}$, jest rozwinięty Szantung. Nie bez znaczenia jest tu duża liczba ludności prowincji, wynosząca ok. 74 mln osób (2004 r.). Prowincje o największym odsetku osób niepiśmiennych w porównaniu do całkowitej liczby ludności to przede wszystkim Tybet, gdzie problem ten dotyczy prawie połowy całej populacji ${ }^{51}$, a także Qinghai (22\%). Prowincjami o najniższym odsetku analfabetów w odniesieniu do ogólnej liczby mieszkańców są leżące na północy Jilin (4\%), Liaoning (4\%), Heilongjiang (5\%), a także - jako miasto wydzielone - Pekin (5\%). Niski odsetek analfabetyzmu oraz korzystna struktura wykształcenia ludności prowincji leżących w historycznej Mandżurii (określanej przez Chińczyków jako tzw. Północny Wschód) wynika z kilku czynników. Wspomniany region ma charakter wybitnie przemysłowy. Bogactwo surowców naturalnych, rozbudowana infrastruktura, przemysłowe tradycje i silne więzi gospodarcze z Rosją oznaczają liczne miejsca pracy. Młodzi ludzie, kończący szkoły średnie oraz studia wyższe np. o profilu technicznym

${ }^{49}$ Cytowane statystyki kwalifikują jako niepiśmienne osoby powyżej 14 roku życia, które nie potrafiły czytać ani pisać lub przychodziło im to z problemami, uniemożliwiając normalną komunikację.

${ }^{50}$ W. R o d z i ń s k i, Historia Chin, Ossolineum, Wrocław 1992, s. 689.

${ }^{51}$ Do niedawna w szkołach podstawowych językiem wykładowym był głównie tybetański, jednak od najmłodszych lat dzieci uczyły się języka chińskiego. Obecnie w Lhasie wszystkie przedmioty, poza językiem tybetańskim, wykładane są po chińsku. W szkołach średnich jedynie nieliczne placówki podtrzymują rolę języka tybetańskiego jako wykładowego. Do kontynuacji nauki na uczelniach wyższych znajomość chińskiego jest niezbędna. 
lub chemicznym zazwyczaj znajdują tu stabilną pracę i dogodne warunki do założenia rodziny. Prawidłowość ta nie dotyczy niewykwalifikowanej kadry robotniczej, która boryka się w tym regionie $\mathrm{z}$ problemem wysokiego bezrobocia, zwłaszcza wobec restrukturyzacji i masowych zwolnień w dużych przedsiębiorstwach państwowych na początku lat dziewięćdziesiątych XX w. Zasilają oni nową falę emigracji do Europy Zachodniej ${ }^{52}$.

$\mathrm{Z}$ analizy struktury chińskiego analfabetyzmu wynika, jak ogromna jest dysproporcja płci - niemal 3/4 liczby osób niepiśmiennych stanowią kobiety. Co ciekawe, problem ten widoczny jest szczególnie w dużych miastach wydzielonych, takich jak Pekin, Tianjin, Szanghaj, a także w zamożnych prowincjach Guangdong i Hajnan, gdzie kobiety stanowią aż 80\% ogólnej liczby analfabetów.

\subsection{Służba zdrowia}

Dostęp do służby zdrowia, poziom usług medycznych oraz wyposażenie szpitali uzależnione są od regionu oraz wielkości miejscowości. Małe szpitale miejskie i okręgowe uchodzą za najgorzej wyposażone i niechętnie są odwiedzane przez osoby zamożniejsze, które wybierają raczej duże szpitale mieszczące się np. w stolicach prowincji. Duże miasta dysponują największą liczbą lekarzy oraz łóżek szpitalnych przypadających na jedną osobę. Biorąc pod uwage powyższe wskaźniki, można stwierdzić, że dostęp do opieki zdrowotnej w Pekinie jest ponad trzykrotnie łatwiejszy niż w prowincji Guizhou.

Dostęp do usług medycznych utrudnia dodatkowo fakt odpłatności za wiele z nich. W miastach pracownicy placówek państwowych oraz pracownicy umysłowi większości średnich i dużych firm prywatnych są objęci ubezpieczeniem zdrowotnym, które gwarantuje im bezpłatny dostęp do opieki zdrowotnej. Kwota przeznaczana przez pracodawcę na ubezpieczenie zdrowotne pracownika nie przekracza obecnie $10 \%$ jego pensji podstawowej ${ }^{53}$. Opieki pozbawieni sa natomiast mieszkańcy wsi, a także niemal wszyscy pracownicy migracyjni. Według szacunków Światowej Organizacji Zdrowia, aż 85\% populacji Chińskiej Republiki Ludowej nie ma ubezpieczenia zdrowotnego ${ }^{54}$.

${ }^{52} \mathrm{P}$. P i c qu a r t, Imperium chińskie. Historia i teraźniejszość chińskiej diaspory, Wydawnictwo Akademickie Dialog, Warszawa 2006.

${ }^{53} \mathrm{~T}$. He s k e th, W. X in g z h u, Health in China: The healthcare market, „British Medical Journal", 31.05.1997, No. 314 (1616), http://www.bmj.com/cgi/content/full/314/7094/1616 (stan z 19.10.2006).

${ }^{54}$ Contry Cooperation Strategy: WHO China. Strategic priorities for 2004-2008. The Office of the World Health Organization Representative in China, Beijing, 31 July 2004 (Final), s. 7, http://www.who.int/countries/chn/en/ (stan z 19.10.2006). 
Tabela 5. Dostęp do opieki zdrowotnej w ChRL (2004)

\begin{tabular}{|l|c|c|c|}
\hline Nazwa & $\begin{array}{c}\text { Liczba osób } \\
\text { przypadających na } \\
\text { 1 lekarza }\end{array}$ & $\begin{array}{c}\text { Liczba łóżek szpitalnych } \\
\text { przypadających } \\
\text { na 1000 os. }\end{array}$ & $\begin{array}{c}\text { Liczba osób } \\
\text { przypadających na } \\
\text { 1 szpital lub klinikę }\end{array}$ \\
\hline Średnia krajowa & 682 & 2,4 & 4384 \\
\hline Guizhou & 1059 & 1,6 & 5858 \\
\hline Anhui & 1002 & 1,9 & 7200 \\
\hline Pekin & 304 & 5,2 & 3088 \\
\hline Szanghaj & 398 & 4,9 & 6829 \\
\hline
\end{tabular}

Źródło: opracowanie własne na podstawie National Bureau of Statistics of China, http://www.stats.gov.cn/tjsj/ndsj/2005/indexeh.htm (stan z 18.10.2006).

Za porady lekarskie, a nawet pomoc w nagłych wypadkach osoby niedysponujące ubezpieczeniem muszą płacić na miejscu, najczęściej gotówką. Doba spędzona w szpitalu kosztuje, w zależności od wielkości i profilu placówki, od kilkuset do ok. tysiąca yuanów. Dla osób zarabiających 500 yuanów miesięcznie jest to bariera nie do przekroczenia. Likwidacja na początku lat osiemdziesiątych popularnego na wsi (szczególnie w okresie rewolucji kulturalnej) systemu tzw. „bosonogich lekarzy” miała zapewnić ludności wiejskiej dostęp do nowoczesnej medycyny. W rzeczywistości uboga ludność została de facto pozbawiona jakiejkolwiek opieki, nie licząc usług świadczonych przez niedyplomowanych znawców medycyny chińskiej i znachorów. Odrębnym problemem jest fakt, że jednym ze źródeł dochodów szpitali (a także lekarzy) jest część zysków od przepisanych pacjentom leków. Zjawisko to może rodzić nietrudne do przewidzenia konsekwencje. W listopadzie 2006 r. prowincją Sichuan wstrząsnął przypadek trzyletniego Xiong Hongweia, który zmarł po przypadkowym spożyciu pestycydów. Szpital odmówił pomocy chłopcu, ponieważ jego dziadek miał przy sobie zaledwie $1 / 5$ kwoty za leczenie, której zażądano. Wydarzenie to spotkało się z gwałtownym protestem miejscowej ludności, która starła się z policją i zdemolowała część szpitala ${ }^{55}$.

Całkowite wydatki na służbę zdrowia w Chińskiej Republice Ludowej stale rosną, średnio o $470 \mathrm{mln}$ rocznie, jednakże w przeliczeniu na 1 mieszkańca nie są imponujące.

${ }^{55}$ Hospital death sparks China riot, BBC, http://news.bbc.co.uk/2/hi/asia-pacific/6140884. stm, 12.11.2006 (stan z 22.11.2006). 


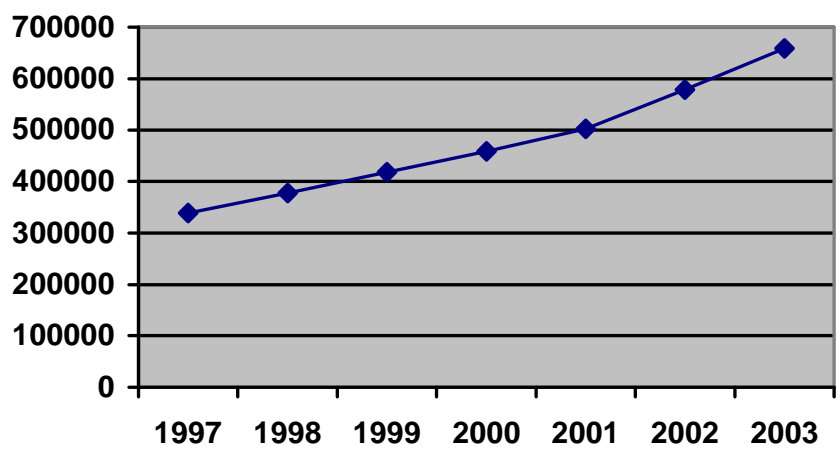

Rys. 7. Wydatki na służbę zdrowia w mln yuanów (lata 1997-2003)

Źródło: opracowanie własne na podstawie National Bureau of Statistics of China, http://www.stats.gov.cn/tjsj/ndsj/2005/indexeh.htm (stan z 18.10.2006).

Według danych Światowej Organizacji Zdrowia, w 2003 r. wydatki te wynosiły ok. 278 dolarów amerykańskich na osobę. Jest to wynik lepszy niż m.in. w Indiach, Wietnamie i Filipinach, ale o wiele gorszy niż np. w Korei czy Malezji. Wydatki na służbę zdrowia w stosunku do całego produktu krajowego brutto wyniosły w Chinach w 2003 r. 5,6\%. Dla porównania, w Polsce wskaźnik ten wynosił 6,5\%, a w Niemczech - 11,1\%.

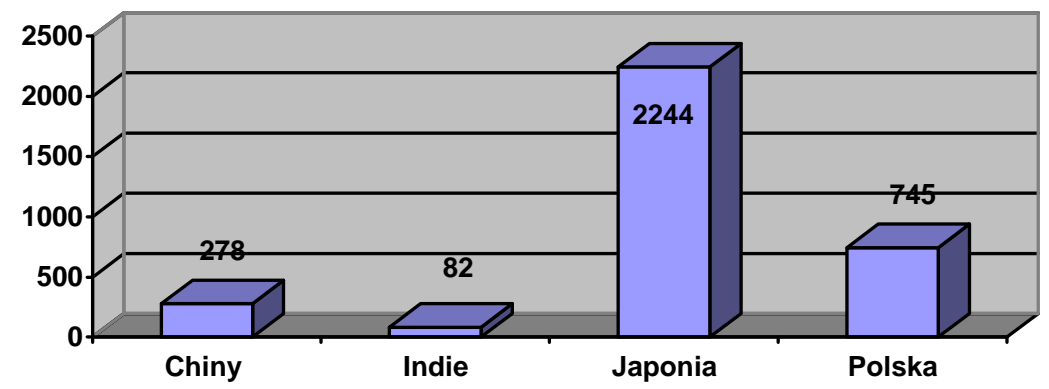

Rys. 8. Wydatki na służbę zdrowia w USD w przeliczeniu na 1 mieszkańca (2003) Źródło: opracowanie własne na podstawie: http://www.unicef.org/infobycountry/china.html (stan 19.11.2006).

\subsection{Wskaźnik śmiertelności niemowląt oraz średniej długości życia}

Jednym ze wskaźników świadczących o stopniu rozwoju cywilizacyjnego, poziomie życia ludności, w tym także o poziomie świadczonych usług zdrowotnych, jest wskaźnik śmiertelności niemowląt i dzieci do 5 roku życia. Analizując powyższy czynnik, zauważyć można ogromne dysproporcje pomiędzy wschod- 
nią i zachodnią częścią Chin. W prowincjach takich jak Zhejiang, Jiangsu, Hebei, Liaoning, Jilin, a także w Pekinie i Szanghaju wskaźnik ten nie przekracza obecnie 12 zgonów na 1000 urodzeń. W prowincjach: Tybet, Xinjiang, Qinghai, Syczuan, Yunnan, Guizhou, Jiangxi, Anhui, a także w okręgu municypalnym Chongqing jest on obecnie pięciokrotnie wyższy i dochodzi do niemal 60 zgonów na 1000 urodzeń $^{56}$.

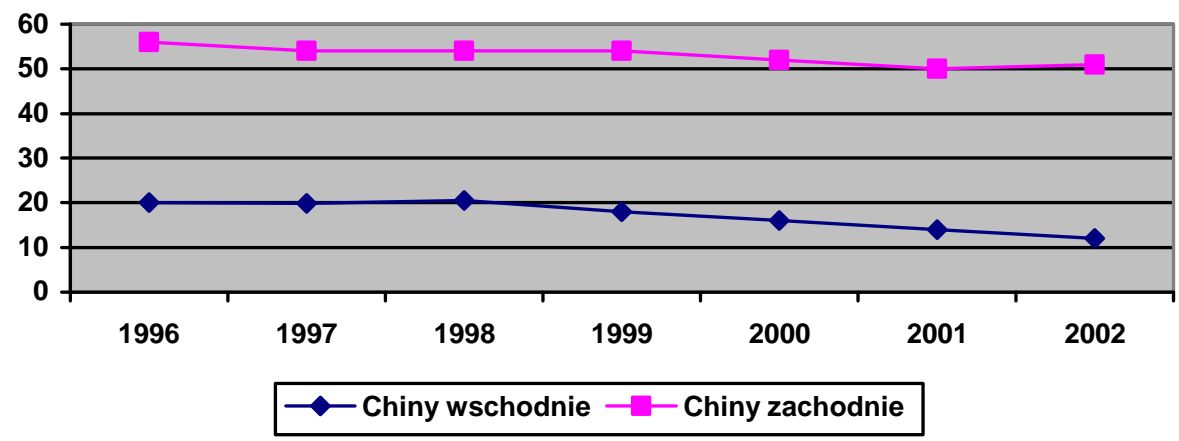

Rys. 9. Śmiertelność niemowląt na 1000 urodzeń (2002)

Źr ód ło: Date Compilation of National Surveillence on Maternal and Child Heath, Ministry of Health of China, 2003, [za:] Country Cooperation Strategy: WHO China. Strategic priorities for 2004-2008, The Office of the World Health Organization Representative in China, Beijing, 31 July 2004 (Final), s. 8, http://www.who.int/countries/chn/en/ (stan z 19.10.2006).

W 2004 r. średnia krajowa wynosiła w Chinach 27 zgonów na 1000 urodzeń, więcej niż w Korei Północnej (21) i o około połowę mniej niż np. w Mongolii, Birmie czy Kambodży.

Wymownym wskaźnikiem, świadczącym o skutkach polaryzacji społeczeństwa chińskiego, są różnice dotyczące średniej długości życia mieszkańców poszczególnych regionów. W 2000 r. średnią długość życia w Chinach szacowano na ok. 71,4 lata ${ }^{57}$. Spośród 14 prowincji, w których długość życia wynosiła mniej niż średnia krajowa, aż 10 było w znacznym lub przeważającym stopniu zamieszkiwanych przez mniejszości etniczne. Warto podkreślić, że średnia długość życia mieszkańców Tybetu (62 lata w 2000 r.) jest o niemal 20 lat krótsza niż np. mieszkańców Hongkongu (81 lat) czy Szanghaju (78 lat).

${ }^{56} 2002$ Date Compilation of National Surveillence on Maternal and Child Heath, Ministry of Health of China, 2003; Contry Cooperation Strategy: WHO China. Strategic priorities for 20042008. The Office of the World Health Organization Representative in China, Beijing, 31 July 2004 (Final), s. 8, http://www.who.int/countries/chn/en/ (stan z 19.10.2006).

${ }^{57}$ Basic Statistics on National Population Census in 1953, 1964, 1982, 1990 and 2000, National Bureau of Statistics of China, http://www.stats.gov.cn/tjsj/ndsj/2005/indexeh.htm (stan z 12.10.2006). 
Tabela 6. Średnia długość życia w Chinach (2000)

\begin{tabular}{|l|c|}
\hline \multicolumn{1}{|c|}{ Nazwa } & Średnia długość życia \\
\hline Tybet & 62,5 \\
\hline Yunnan & 64,2 \\
\hline Guizhou & 64,5 \\
\hline Qinghai & 64,6 \\
\hline Xinjiang & 66,0 \\
\hline Mongolia Wewnętrzna & 68,3 \\
\hline Ningxia & 68,7 \\
\hline Hunan & 69,1 \\
\hline Guangxi & 69,1 \\
\hline Syczuan & 69,3 \\
\hline Średnia krajowa & $\mathbf{7 1 , 4}$ \\
\hline Szanghaj & $\mathbf{7 8 , 1}$ \\
\hline Hongkong & $\mathbf{8 1 , 0}$ \\
\hline
\end{tabular}

Źródło: opracowanie własne na podstawie National Bureau of Statistics of China, http://www.stats.gov.cn/tjsj/ndsj/2005/indexeh.htm (stan 12.10.2006); 2005 World Population Data Sheet of the Population Reference Bureau, Waszyngton 2005, www.prb.org (stan z 21.10.2006).

Biorąc pod uwagę poziom i średnią długość życia mieszkańców Tybetu, dostęp do edukacji, opieki zdrowotnej, a także dóbr trwałych, można stwierdzić, że region ten pod względem rozwoju pozostaje o kilkadziesiąt lat $\mathrm{w}$ tyle za prowincjami nadmorskimi. Można zastanawiać się, czy sytuacja ta wynika wyłącznie ze specyfiki regionu oraz kultury i systemu wartości zamieszkującej go ludności, czy może raczej z dotychczasowego braku chęci lub koncepcji wyrównywania szans w różnych regionach kraju. Otwarcie w 2006 r. kolei łączącej Lhasę ze światem zewnętrznym stanowi przykład działań chińskiego rządu, które mają doprowadzić do zmniejszenia dysproporcji w rozwoju prowincji wschodnich i zachodnich. Działania te obejmują rozbudowę infrastruktury, przyciaganie inwestycji, zachęcanie Chińczyków Han do przesiedlania się do słabiej rozwiniętych prowincji i kuszenie ich atrakcyjnymi zarobkami, rozbudowa miast na modłę tych ze wschodniej części Chin. Polityka ta, prowadzona nie tylko wobec Tybetu, lecz także wobec prowincji Xinjiang, Qinghai, Mongolia Wewnętrzna itd., budzi wiele kontrowersji i niezadowolenia wśród miejscowej ludności niechińskiej. Podstawowym zarzutem wobec niej jest wielopłaszczyznowa sinizacja zacofanych regionów. Działania te mają również na celu silniejsze związanie wspomnianych regionów z Chinami właściwymi. Rząd chiński prowadzi od końca lat dziewięćdziesiątych intensywną kampanię propagandową, podkreślającą znaczenie prowincji zachodnich dla ogólnonaro- 
dowego rozwoju. Do prowincji zachodnich zaliczono 12: Xinjiang, Tybet, Qinghai, Mongolię Wewnętrzną, Ningxia, Gansu, Syczuan, Shaanxi, Chongqing, Guizhou, Guangxi oraz Yunnan. Zajmują one w sumie ponad 2/3 terytorium ChRL, ale jej mieszkańcy stanowią zaledwie $1 / 4$ populacji.

\subsection{Wystąpienia społeczne}

Dyskryminacja ubogiej ludności pod względem dostępu do opieki medycznej, systemu edukacji, rynku pracy, a także rozgoryczenie wynikające z rosnącej polaryzacji społeczeństwa i bolesne koszty rozwoju gospodarczego coraz częściej prowadzą w Chinach do wystąpień i demonstracji. Deng Xiaoping przestrzegał, że niezadowolenie ludności wiejskiej może w przyszłości zachwiać stabilnością państwa:

Jeśli nie zapewni się rozwiązania życiowych problemów tych 80 proc. mieszkańców kraju, nie sposób osiagnąć społecznej stabilizacji ${ }^{58}$.

Do najważniejszych przyczyn niepokojów społecznych we współczesnych Chinach zaliczyć należy: wotnej;

- brak powszechnego i bezpłatnego dostępu do podstawowej opieki zdro-

- brak lub ograniczone możliwości zdobywania wykształcenia przez uboga ludność;

- bezrobocie, w tym również bezrobocie ukryte na wsi;

- niewypłacanie wynagrodzeń przez pracodawców bądź niewypłacalnie ich w terminie, a także inne przejawy łamania prawa pracy;

- przymusowe przesiedlanie ludności w związku z planami rozbudowy lokalnej infrastruktury, odbieranie chłopom ziemi rolnej, zazwyczaj za niewielką rekompensatą;

- obciążenia finansowe, nakładane na ludność przez rząd centralny i władze lokalne (np. dodatkowe opłaty przeznaczane na rozbudowę lokalnych dróg i autostrad);

- rosnącą różnicę poziomu życia w mieście i na wsi;

- korupcję;

- wszechwładzę lokalnych urzędników i służb porządkowych;

- bezwzględne egzekwowanie polityki kontroli urodzeń;

- dewastację środowiska naturalnego i jej skutki dla lokalnych społeczności;

- uboczne skutki gwałtownej urbanizacji.

${ }^{58} \mathrm{D} . \quad \mathrm{X}$ i a o p in g, W sferze politycznej rozwijać demokracje, $w$ dziedzinie ekonomicznej realizować reformy, 15.04.1985, [w:] Chińska droga do socjalizmu, s. 312. 
Od tysiącleci bunt był w Chinach powszechną formą wyrażania przez lud sprzeciwu wobec niesprawiedliwości i złych rządów. Złagodzenie reżimu po śmierci Mao i rozpoczęcie reform gospodarczych sprawiło, że z roku na rok rośnie liczba wystapień społecznych w Chinach. Chińskie Ministerstwo Bezpieczeństwa Publicznego podaje, iż w 2003 r. odnotowano ponad 58 tys. wystapień o rozmaitym tle i zasięgu, w 2004 r. - 74 tys., a w 2005 r. już ok. 87 tys. ${ }^{59}$ Oznacza to, że w 2005 r. każdego dnia dochodziło średnio do 238 buntów i demonstracji, a więc do niemal 10 na godzinę. Władze chińskie zdają sobie sprawę z zagrożeń, jakie może nieść ze sobą niezadowolenie społeczne. $Z$ coraz większą determinacją walczą $\mathrm{z}$ przywódcami i uczestnikami protestów. W grudniu 2005 r. zagraniczna prasa odnotowała najpoważniejszy - i najprawdopodobniej pierwszy - od czasu wydarzeń na placu Tian'anmen w 1989 r. przypadek użycia przez policję ostrej amunicji przeciwko demonstrantom. We wsi Dongzhou (prow. Guangdong) chłopi protestowali przeciwko przesiedleniu i wywłaszczeniu ich za niewielką rekompensatą z terenów przeznaczonych pod budowę elektrowni. Oficjalnie potwierdzono śmierć 3 demonstrantów, jednak rzeczywistą liczbę ofiar zamieszek szacować można na ok. 20 osób $^{60}$. W maju 2006 r. 13 uczestników demonstracji w Dongzhou skazano na kary do 7 lat więzienia ${ }^{61}$. W obronie rolników z Dongzhou stanęło ponad 50 chińskich intelektualistów, którzy w liście otwartym potępili fakt użycia wobec nich siły. Można mieć nadzieję, że nie jest to jednorazowy gest, lecz symbol początku szerszej współpracy w obronie praw pokrzywdzonych. Z powodu Igrzysk Olimpijskich w Pekinie baczniejszym wzrokiem ku Chinom spoglądały zagraniczne media, co budzi nadzieję, że będą donosić o kolejnych wystąpieniach, których liczba w przyszłości z pewnością będzie rosła.

Czy rosnące społeczne niezadowolenie i odwaga cywilna tych, którzy nie boją się demonstrować w obronie swych praw może degradować chiński system polityczny? Dzięki innowacjom technologicznym oraz rozbudowanej infrastrukturze poprawia się organizacyjna struktura protestów. Jednakże ze względu na ich lokalny charakter oraz brak koordynacji pomiędzy nimi jest mało prawdopodobne, by w najbliższym czasie mogło dojść do wystapień o szerszym, ponadregionalnym zasięgu i większej mocy oddziaływania. Realne zagrożenie dla Komunistycznej Partii Chin mogłaby stanowić unia między ludnością wiejską, robotnikami i inteligencją, wyłonienie społecznego lidera lub liderów oraz wysunięcie powszechnych żądań politycznych lub społecznych. Na razie jednak partia rządząca kontroluje sytuację w Chińskiej Republice Ludowej.

${ }^{59}$ T. L u m, Social Unrest in China, CRS Report for Congress, The Library of Congress, 2006, CRS-1, CRS-2.

${ }^{60}$ Human Rights Watch, Dongzhou Killings Need Independent Investigation. Chinese Citizens Launch Public Call for Impartial Probe, 15.12.2005, http://hrw.org/english/docs/2005/ 12/15/china12281.htm (stan z 13.11.2006).

${ }^{61}$ Ibidem. 